\title{
Studies on Helminth parasites of Indian fishes. Part. III. On some species of the genus Allocreadium Looss, 1900.
}

\author{
by Vijay Laxmi KAKAJI * \\ (Department of Zoology, University of Lucknow, U.P. India)
}

\begin{abstract}
Résumé
Un grand nombre de Trématodes du genre Allocreadium Looss 1900, ont été récoltés chez des poissons d'eau douce en Inde. Deux espèces nouvelles sont décrites: $A$. fasciatusi et $A$. guptai; cinq espèces font l'objet d'une redescription: $A$. handiai, A. thapari, A. mehrai, $A$. singhi et A. heteropneustusius. Tombent en synonymie: $A$. ophiocephali avec $A$. handiai; $A$. spindale et Rhynchocreadium singhia avec $A$. mehrai, et $A$ : mahseri avec $A$. nicolli. Une clé des espèces indiennes du genre Allocreadium est donnée.
\end{abstract}

\section{Summary}

A large number of trematodes of the genus Allocreadium Looss, 1900 were collected from fresh water fishes of India. Of these two new species namely $A$. fasciatusi n. sp. and $A$. guptai n. sp. are described from fresh water fishes of Trichogaster fasciatus and Rita rita respectively. In addition five redescriptions namely $A$. handiai Pande, 1937 from Ophicephalus punctatus; A. thapari Gupta, 1950 from Rita rita; A. mehrai Gupta, 1956 from Rhynchobdella aculeata; A. singhi Rai, 1962 from Rita rita and $A$. heteropneustusius Agrawal, 1964 from Mystus seenghala are given. $A$. ophiocephali is considered to be a synonym of $A$. handiai; $A$. spindale and Rhynchocreadium singhia a synonym of $A$. mehrai and $A$, mahseri a synonym of A. nicolli. A key to the Indian species of the genus Allocreadium Looss, 1900 is given.

The paratype and holotye specimens of the forms described in this paper will be deposited in Dr. G. S. Thapar's Helminthological Collection, Lucknow, U.P. India.

The author wishes to tender her deep gratitude to Dr. S. P. Gupta, Reader in Zoology, Lucknow University, for his supervision. Thanks are also due to S.C.S.I.R. authorities for a research grant under which the present work was being carried out. 


\section{Introduction.}

Looss (1900) created the genus Allocreadium with $A$. isoporum as its type species. Since then a large number of species have been reported from various parts of World. Of these the following species have been reported from India namely, $A$. annandalei Southwell, 1913, A. handiai Pande, 1937, A. mahaseri Pande, 1938, A. schizothoracis Pande, 1938, A. nicolli Pande, 1938, A. kosia Pande, 1938, A. thapari Gupta, 1950, A. nemachilus Kaw, 1950, A. mehrai Gupta, 1956, A. kamalai Gupta, 1956, A. spindale Saxsena, 1958, A. ophiocephali Srivastava, 1960, A. makundi Gupta, 1961, A. dollfusi Rai, 1962, A. singhi Rai, 1962, A. hirnai Rai, 1962 and A. heteropneustusius Agrawal, 1964.

Mehra (1966) revised the classification of Allocreadidea Nicoll, 1934 and recognised the following valid Indian species under the genus Allocreadium namely, $A$. handiai Pande, 1937 (Syn. A. thapari Gupta, 1956, A. ophiocephali Srivastava, 1960), A. mahaseri Pande, 1938, A. nicolli Pande, 1938, A. kosia Pande, 1938, A. schizothoracis Pande, 1938, A. nemachilus Kaw, 1950, A. mehrai Gupta, 1956 and A. kamalai Gupta, 1956.

I disagree with Mehra (1966) who considered that $A$. thapari to be a synonym of A. handiai. A. thapari is distinct from $A$. handiai in the position of testes and receptaculum seminis and relative size of eggs.

Pande (1938) distinguished $A$. mahaseri from $A$. nicolli on account of the smaller size of body, in having suckers of equal size, more forward position of genital pore in relation to intestinal bifurcation, testes tandem and contiguous, in the absence of uterine coils extending beyond anterior border of anterior testis and large size of eggs. A. mahaseri is distinct from A. nicolli in having larger size of body, and testes slightly separated from each other. In the opinion of author the above distinguishing characters are variable and hence both are identical forms. Accordingly A. mahaseri is considered a synonym of $A$. nicolli.

\section{ALLOCREADIUM FASCIATUSI n. sp. (Figs. 1-7).}

Eight specimens were collected from the intestine of a fresh water fish, Trichogaster fasciatus (Bloch et Schneider) from Lucknow.

Descriptions : body elongated, smooth, aspinose, rounded at extremities, 3.33 to $6.50 \mathrm{~mm}$. long, 0.70 to $1.5 \mathrm{~mm}$. wide. Oral sucker subterminal, spherical or ovoid, 0.22 to $0.39 \mathrm{~mm}$. long, 0.23 to $0.40 \mathrm{~mm}$. wide. Ventral sucker spherical, preequatorial, equal or larger than oral sucker, 0.18 to $0.40 \mathrm{~mm}$. long, 0.18 to $0.43 \mathrm{~mm}$. wide at 0.99 to $1.68 \mathrm{~mm}$. from anterior extremity. Prepharynx absent; pharynx muscular, ovoid, 0,10 to $0.20 \mathrm{~mm}$. long, 0.12 to $0.21 \mathrm{~mm}$. wide ; esophagus tubular, straight, 0.10 to $0.20 \mathrm{~mm}$. long ; caeca simple, extending upto posterior region of body.

Genital pore median or submedian, intercaecal, at 0.80 to $1.95 \mathrm{~mm}$. from anterior extremity.

Excretory pore terminal at posterior end of body; bladder Y-shaped extending upto hind end of posterior testis. 

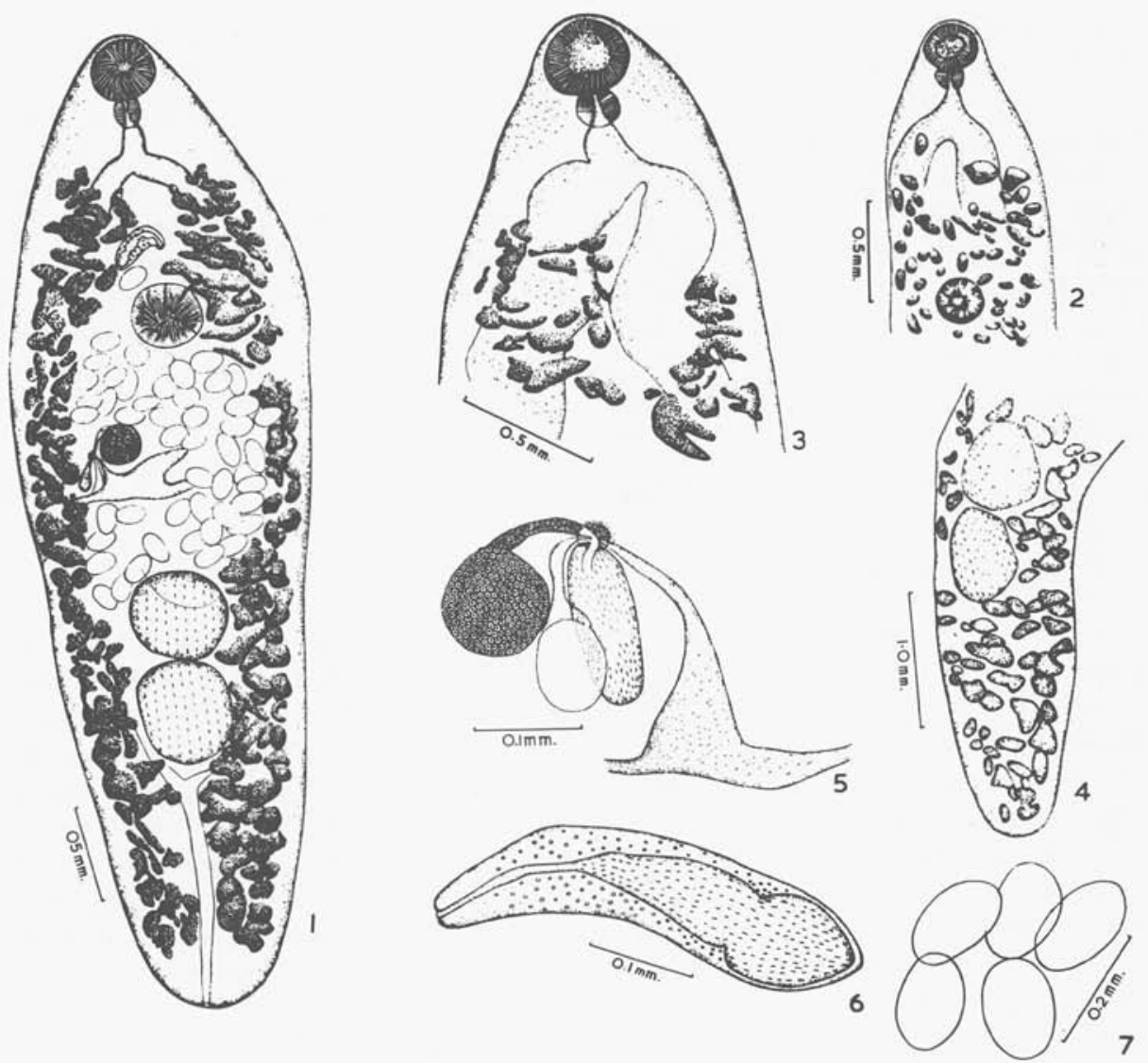

Allocreadium fasciatusi n. sp. FIg. 1. - Dorsal view. FIG. 2. - Anterior end showing ventral sucker smaller than oral sucker. FIG. 3. - Anterior end showing extension of vitellaria from some distance behind intestinal bifurcation. FIG. 4. - Hind end showing poserior testis smaller than anterior testis. FIG. 5. - Ootype enlarged. FIG. 6. - Cirrus pouch en!arged. FIG. 7: - Eggs

Testes entire, oval or spherical, tandem and postequatorial. Anterior testis postovarian 0.31 to $0.51 \mathrm{~mm}$. long, 0.31 to $0.56 \mathrm{~mm}$. wide at 1.56 to $3.4 \mathrm{~mm}$. from anterior extremity. Posterior testis smaller, larger, close or slightly apart from anterior testis, 0.20 to $0.52 \mathrm{~mm}$. long, 0.31 to $0.50 \mathrm{~mm}$. wide at 0.85 to $1.70 \mathrm{~mm}$. from hind end. Cirrus sac flask shaped lying between ventral sucker and intestinal bifurcation and extends from genital pore to middle region of ventral sucker. It measures 0.31 to $0.46 \mathrm{~mm}$. long, 0.07 to $0.09 \mathrm{~mm}$. wide at 0.75 to $1.95 \mathrm{~mm}$. from anterior extremity. Vesicula seminalis bipartite lying at basal part of cirrus sac; proximal part 0.08 to $0.14 \mathrm{~mm}$. long, 0.05 to $0.08 \mathrm{~mm}$. wide, while distal part smaller, 0.05 to $0.06 \mathrm{~mm}$. long, 0.04 to $0.06 \mathrm{~mm}$. wide. Anterior to vesicula seminalis a short pars prostatica, 0.05 to $1.14 \mathrm{~mm}$. long opening into a muscular cirrus through an ejaculatory duct, 
0.10 to $0.12 \mathrm{~mm}$. long. Space around vesicula seminalis and pars prostatica surrounded by a large number of prostate gland cells.

Ovary entire, oval or spherical, equatorial or pre equatorial, pre testicular, lying between ventral sucker and anterior testis. It measures 0.12 to $0.29 \mathrm{~mm}$. long, 0.12 to $0.25 \mathrm{~mm}$. wide at 1.21 to $2.5 \mathrm{~mm}$. from anterior extremity. From anterior end of ovary arises oviduct which opens at ootype. Receptaculum seminis elongated or pear shaped, lying lateral to ovary, 0.21 to $0.27 \mathrm{~mm}$. long, 0.06 to $0.12 \mathrm{~mm}$. wide. Vitellaria follicular, extending from hind end of intestinal bifurcation upto hind end of body. Vitellaria mainly lateral in position anterior to ventral sucker but behind posterior testis filling intercaecal space. Uterine coils lying between genital pore and anterior testis. Eggs oval and operculated, 0.11 to $0.16 \mathrm{~mm}$. long, 0.15 to $0.22 \mathrm{~mm}$. wide.

Host : Trichogaster fasciatus (Bloch. and Schneider).

LOCATION : Intestine.

Locality : Lucknow.

Discussion: The new form differs from all the known species of the genus Allocreadium in the extension of vitellaria from hind end of intestinal bifurcation to posterior end of body. The vitellaria extend in A. annandalei Southwell, 1913, A. handiai Pande, 1937, A. schizothoracis Pande, 1938, A. thapari Gupta, 1951, A. dollfusi Rai, 1962, A. hirnai Rai, 1962 and A. heteropneustusius Agrawal, 1964 from hind end of ventral sucker to posterior end of body ; in A. mahaseri Pande, 1938, A. nicolli Pande, 1938, A. nemachilus Kaw, 1950 and $A$. singhi Rai, 1964 from anterior end of ventral sucker to hind end of body; in A. kosia Pande, 1938 and A. makundi Gupta, 1961 from middle of ventral sucker to hind end of body; in A. mehrai (Syn. A. spindale Saksena, 1958) from anterior end of ovary to hind end of body and in A. kamalai Gupta, 1956 from hind end of oral sucker to posterior end of body. The new form resembles closely $A$. kamalai in the relative size of ventral sucker, in the size of esophagus, in the position of cirrus sac but however differs from it in the extension of vitellaria, in the position of receptaculum seminis and genital pore and in the absence of prepharynx. Accordingly it is regarded as new with the specific name $A$. fasciatusi n. sp.

\section{ALLOCREADIUM GUPTAI. n. sp. (Fig. 8).}

Only one specimen was collected from the intestine of a fresh water fish Rita rita (Ham.) from Varanasi.

DESCRIPTION : Body elongated, aspinose, narrow at anterior end broader at posterior end, $1.28 \mathrm{~mm}$. long, $0.50 \mathrm{~mm}$. wide. Oral sucker ovoid, terminal, $0.13 \mathrm{~mm}$. long, $0.125 \mathrm{~mm}$. wide. Ventral sucker spherical, larger than oral sucker, $0.21 \mathrm{~mm}$. in diameter at $0.36 \mathrm{~mm}$. from anterior extremity. Prepharynx $0.01 \mathrm{~mm}$. long, $0.02 \mathrm{~mm}$. wide ; pharynx muscular, ovoid, $0.06 \mathrm{~mm}$. long, $0.072 \mathrm{~mm}$. wide ; esophagus tubular, $0.15 \mathrm{~mm}$. long; caeca simple extending upto hind end of posterior iestis. 
Genital pore submedian, nearly midway between intestinal bifurcation and ventral sucker at $0.32 \mathrm{~mm}$. from anterior extremity.

Excretory pore terminal at posterior end of body; bladder tubular extending upto hind of posterior testis.

Testes entire, oval, diagonal, lying near middle of posterior half of body. Anterior testis $0.1 \mathrm{~mm}$. long. $0.19 \mathrm{~mm}$. wide at $0.83 \mathrm{~mm}$. from anterior end. Posterior testis lying just behind anterior testis, larger than anterior testis, $0.22 \mathrm{~mm}$. long, $0.23 \mathrm{~mm}$. wide at 0.32 $\mathrm{mm}$. from hind end of body. Cirrus sac crescent shaped lying on right side of ventral sucker extending from genital pore to a slightly behind its hinder margin. It measures 0.27 $\mathrm{mm}$. long, $0.16 \mathrm{~mm}$. wide at $0.32 \mathrm{~mm}$. from anterior extremity. Vesicula seminalis bipartite lying in basal part of cirrus sac ; proximal part $0.14 \mathrm{~mm}$. long, $0.05 \mathrm{~mm}$. wide while distal part $0.03 \mathrm{~mm}$. long, $0.05 \mathrm{~mm}$. wide; pars prostatica $0.03 \mathrm{~mm}$. long, $0.03 \mathrm{~mm}$. wide, opening into a long muscular cirrus through a narrow ejaculatory duct, $0.18 \mathrm{~mm}$. long. Space around vesicula seminalis and pars prostatica in cirrus sac filled with prostate gland cells.

Ovary entire, kidney shaped, post equatorial, immediatley infront of anterior testis, $0.1 \mathrm{~mm}$. long, $0.19 \mathrm{~mm}$. wide at $0.83 \mathrm{~mm}$. from anterior extremity. Vitellaria follicular, extending from middle of esophagus to hind end of body, mainly lateral in position but

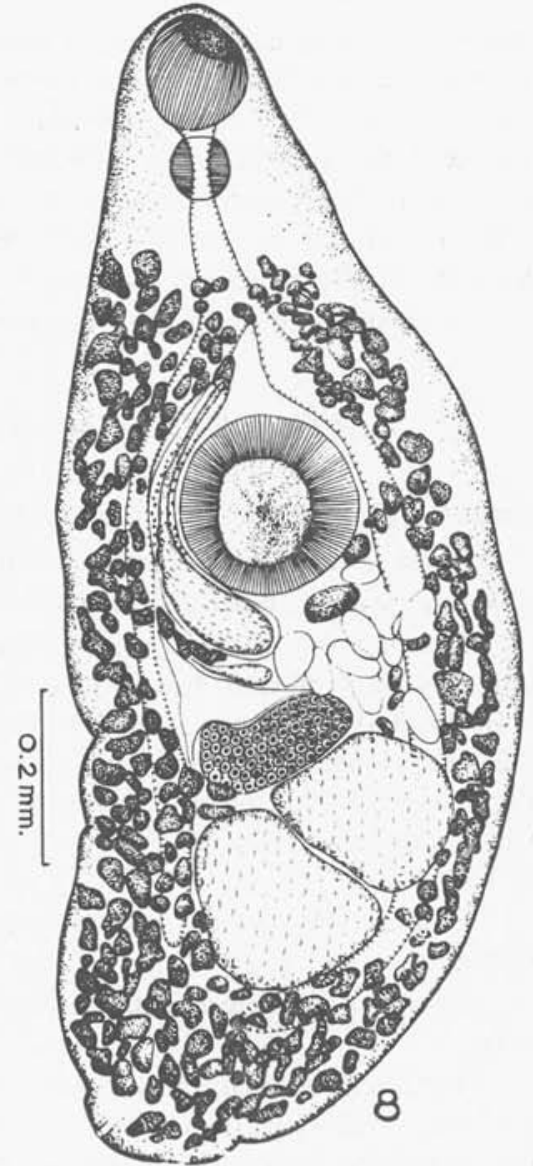

FIG. 8. - Allocreadium guptai n. sp. Dorsal view cover intestinal caeca and space behind posterior testis. Uterine coils with 11 eggs lying transversely between anterior testis and ventral sucker. Eggs avoid, non operculated, 0.02 to $0.03 \mathrm{~mm}$. long, 0.06 to $0.08 \mathrm{~mm}$. wide.

\section{Host : Rita rita (Ham.).}

LOCATION : Intestine.

LOCALITY : Varanasi.

Discussion: The new form differs from all the known species of the genus Allocreadium except $A$. kosia and $A$. dollfusi in the extension of cirrus sac backward to posterior end of ventral sucker. The new form differs from both the forms in having ventral sucker larger than oral sucker, in having receptaculum seminis anterior to ovary instead of posterior to it, in the extension of vitellaria from middle of esophagus to 
hind end of body and in having genital pore midway between intestinal bifurcation and ventral sucker instead of at the level of intestinal bifurcation. The new form further can be distinguished from $A$. dollfusi in the extension of cirrus sac a little behind the ventral sucker instead of upto anterior end of ovary. The new form resembles closely A. kosia in the extension of cirrus sac a little posterior to ventral sucker, but differs from it in the extension of intestinal caeca upto hind end of posterior testis instead of a short distance infront of hind end of body.

Accordingly it is regarded as new with the specific name A. guptai n. sp.

\section{ALLOCREADIUM HANDIA Pande, 1937 (Figs. 9-11)}

Syn. A. ophiocephali Srivastava, 1960.

Four specimens were collected from the intestine of a fresh water fish, Ophicephalus punctatus (Bloch.) from river Gomati at Lucknow.

DESCRIPTION : Body elongated, aspinose, rounded at extremities, 1.33 to $2.85 \mathrm{~mm}$. long, 0.41 to $0.88 \mathrm{~mm}$. wide. Oral sucker spherical, terminal, 0.21 to $0.39 \mathrm{~mm}$. long, 0.41 to $0.88 \mathrm{~mm}$. wide. Ventral sucker ovoid, smaller than oral sucker, 0.12 to $0.23 \mathrm{~mm}$. long, 0.15 to $0.30 \mathrm{~mm}$. wide at 0.45 to $0.82 \mathrm{~mm}$. from anterior extremity. Prepharynx absent ; pharynx muscular, ovoid, 0.10 to $0.13 \mathrm{~mm}$. long, 0.08 to $0.13 \mathrm{~mm}$. wide ; esophagus short, 0.05 to $0.66 \mathrm{~mm}$. long ; caeca simple extending upto hind end of body.

Genital pore median or submedian, intercaecal at 0.60 to $0.68 \mathrm{~mm}$. from anterior extremity.

Excretory pore terminal ; bladder tubular extending upto hind end of posterior testis.

Testes entire, oval, tandem and lying in middle of body. Anterior testis, 0.08 to $0.13 \mathrm{~mm}$. long, 0.022 to $0.033 \mathrm{~mm}$. wide at 0.65 to $1.29 \mathrm{~mm}$. from anterior extremity. Posterior testis lying just behind anterior testis, larger, 0.14 to $0.39 \mathrm{~mm}$. long, 0.12 to $0.33 \mathrm{~mm}$. wide at 0.46 to $1.01 \mathrm{~mm}$. from posterior extremity. Cirrus sac flask shaped, median lying obliquely between intestinal bifurcation and ventral sucker, 0.183 to $0.25 \mathrm{~mm}$. long, 0.14 to $0.18 \mathrm{~mm}$. wide at 0.50 to $0.62 \mathrm{~mm}$. from anterior extremity. Vesicula seminalis bipartite lying in basal part of cirrus sac ; proximal part, 0.05 to $0.08 \mathrm{~mm}$. long, 0.05 to $0.08 \mathrm{~mm}$. wide ; while distal part 0.07 to $0.08 \mathrm{~mm}$. long, 0.09 to $0.1 \mathrm{~mm}$. wide. Anterior to vesicula seminalis a short pars prostatica, 0.04 to $0.05 \mathrm{~mm}$. long, 0.02 to $0.05 \mathrm{~mm}$. wide, opening into a muscular cirrus through an ejaculatory duct, 0.06 to $0.15 \mathrm{~mm}$. long. Space around vesicula seminalis and pars prostatica surrounded by a large number of prostate gland cells.

Ovary entire, oval or spherical, preequatorial, pretesticular and lying just behind ventral sucker or slightly lateral to it. It measures 0.10 to $0.22 \mathrm{~mm}$. long, 0.06 to $0.19 \mathrm{~mm}$. wide at 0.58 to $1.08 \mathrm{~mm}$. from anterior extremity. From anterior end of ovary arises oviduct which opens at ootype. Receptaculum seminis pear shaped lying lateral or posterior to ovary, 0.13 to $0.19 \mathrm{~mm}$. long, 0.02 to $0.09 \mathrm{~mm}$. wide. Vitellaria 
follicular, extending from hind end of ventral sucker upto a little anterior from hind end of body; mainly lateral in position but filling intercaecal space behind posterior testis. Uterine coils lying between genital pore and anterior testis. Eggs oval, 0.12 to $0.13 \mathrm{~mm}$. long, 0.07 to $0.08 \mathrm{~mm}$. wide.
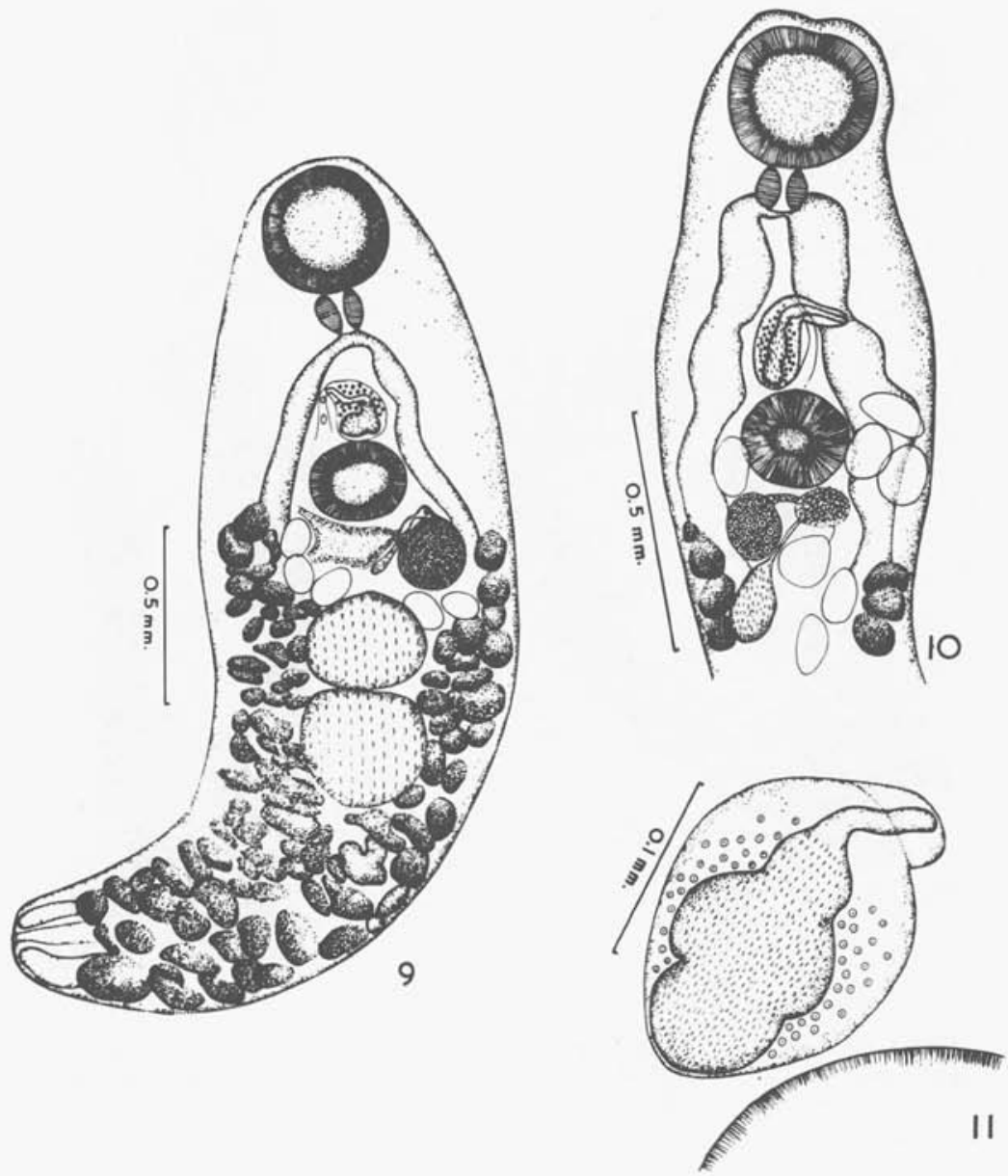

Allocreadium handiai Pande, 1937. Fig. 9. - Ventral view. Fig. 10. - Dorsal view. FIG. 11. - Cirrus pouch enlarged

Host : Ophicephalus punctatus (Bloch.).

LOCATION : Intestine.

LOCALITY : Lucknow. 
Discussion: The present form belongs to A. handiai Pande, 1937 (syn. A. ophiocephali Srivastava, 1960) but differs from it in having oesophagus absent or shorter than pharynx and in the relative size of eggs.
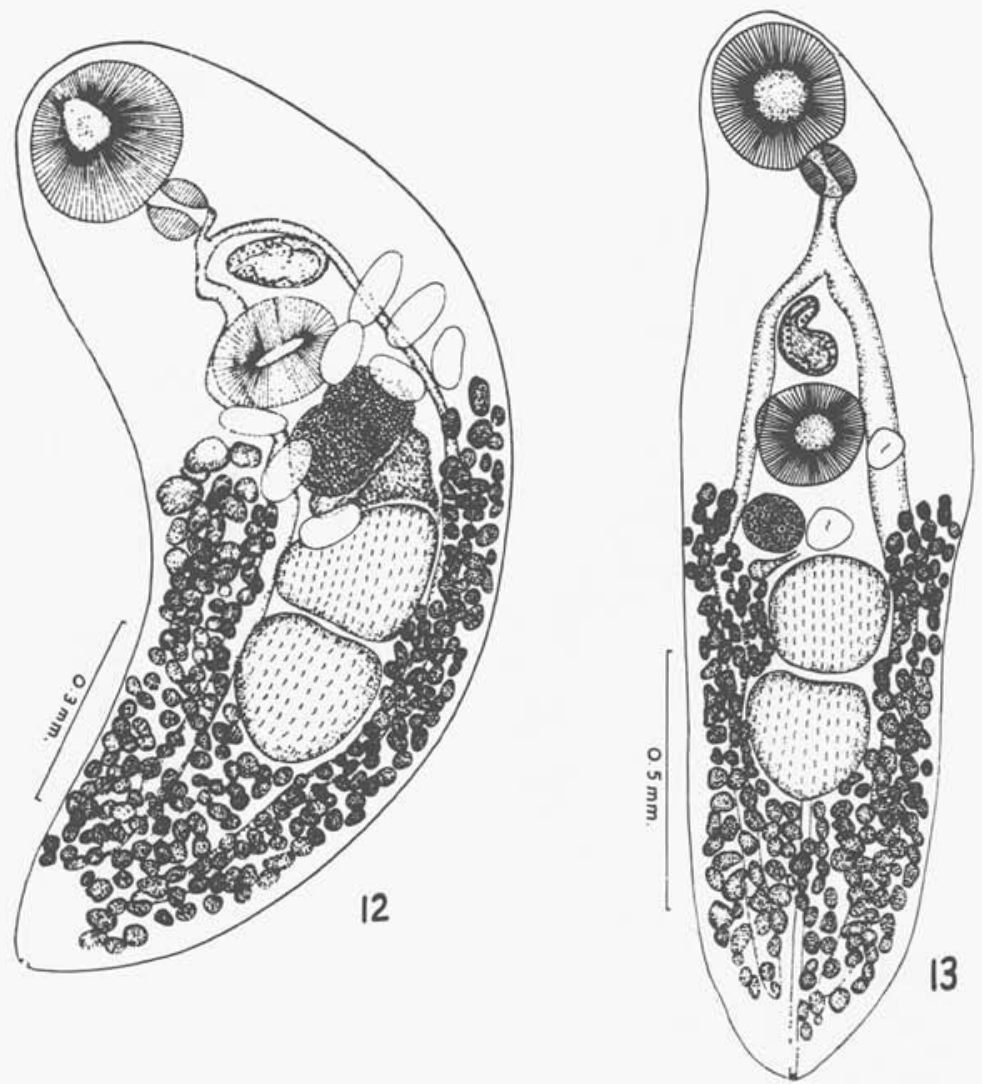

Allocreadium thapari Gupta, 1950. FIG. 12. - Ventral view, showing anterior testis larger than posterior. FIG. 13. - Esophagus larger than pharynx and posterior testis larger than anterior

Srivastava (1960) created A. ophiocepha'i from Ophicephalus punctatus and distinguished it from $A$. handiai in the shape and relative size of testes, in the size of receptaculum seminis and vesicula seminalis and in the extension of excretory bladder. In the opinion of author these characters are specific variations and hence is infavour of Mehra, 1960 in considering $A$. ophiocephali to be a synonym of $A$. handiai. 


\section{ALLOCREADIUM THAPARI Gupta, 1950 (Figs. 12-13)}

Numerous specimens were collected from the intestine of a fresh water fish, Rita rita (Ham.) from river Gomati at Lucknow.

DESCRIPTION (based on 6 specimens) : Body elongated, aspinose, rounded at both extremities, 1.29 to $2.3 \mathrm{~mm}$. long, 0.41 to $0.51 \mathrm{~mm}$. wide. Oral sucker terminal, spherical, 0.2 to $0.26 \mathrm{~mm}$. long, 0.2 to $0.29 \mathrm{~mm}$. wide. Ventral sucker smaller than oral sucker, 0.15 to $0.20 \mathrm{~mm}$. long, 0.15 to $0.22 \mathrm{~mm}$. wide at 0.48 to $0.70 \mathrm{~mm}$. from anterior extremity. Prepharynx absent ; pharynx 0.09 to $0.10 \mathrm{~mm}$. long, 0.08 to $0.10 \mathrm{~mm}$. wide ; esophagus absent or present, tubular, 0.04 to $0.12 \mathrm{~mm}$. long ; caeca simple, extending upto a little anterior from hind end of body.

Genital pore median or submedian, intercaecal, preacetabular at, 0.40 to $0.59 \mathrm{~mm}$. from anterior extremity.

Excretory pore terminal ; bladder tubular extending upto hind end of ovary.

Testes entire or lobed, oval, postequatorial, tandem, lying in anterior half of hind end of body. Anterior testis, 0.15 to $0.25 \mathrm{~mm}$. long, 0.16 to $0.30 \mathrm{~mm}$. wide at 0.69 to $1.1 \mathrm{~mm}$. from anterior extremity. Posterior testis lying just behind anterior testis, larger or smaller than anterior testis, 0.19 to $0.29 \mathrm{~mm}$. long, 0.21 to $0.29 \mathrm{~mm}$. wide at 0.30 to $0.71 \mathrm{~mm}$. from hind end. Cirrus sac flask shaped, median, lying obliquely between intestinal bifurcation and ventral sucker, 0.11 to $0.26 \mathrm{~mm}$. long, 0.05 to $0.11 \mathrm{~mm}$. wide at 0.69 to $1.1 \mathrm{~mm}$. from anterior extremity. Vesicula seminalis bipartite lying in basal part of cirrus sac ; proximal part 0.02 to $0.06 \mathrm{~mm}$. long, 0.03 to $0.07 \mathrm{~mm}$. wide while distal part, 0.03 to $0.07 \mathrm{~mm}$. long, 0.03 to $0.08 \mathrm{~mm}$. wide ; pars prostatica, 0.02 to $0.05 \mathrm{~mm}$. long, 0.02 to $0.06 \mathrm{~mm}$. wide opening into a muscular cirrus through a narrow ejaculatory duct, 0.05 to $0.15 \mathrm{~mm}$. long. Space around vesicula seminalis and pars prostatica in cirrus sac filled with prostate gland cells.

Ovary entire, spherical, preequatorial, infront of anterior testis just behind ventral sucker, 0.08 to $0.15 \mathrm{~mm}$. long, 0.09 to $0.16 \mathrm{~mm}$. wide at 0.61 to $0.95 \mathrm{~mm}$. from anterior extremity. Receptaculum seminis pear shaped, lying postero-dorsal or posterolateral to ovary just infront of anterior testis, 0.07 to $0.1 \mathrm{~mm}$. long, 0.06 to $0.11 \mathrm{~mm}$. wide at 0.75 to $0.96 \mathrm{~mm}$. from anterior extremity. Vitellaria follicular, extending from hind end of ventral sucker upto posterior end of body, mainly lateral in position, but cover intestinal caeca and space behind posterior testis. Uterine coils extending from genital pore upto anterior end of anterior testis. Eggs non operculated, few in number, 0.07 to $0.12 \mathrm{~mm}$. long, 0.05 to $0.14 \mathrm{~mm}$. wide.

Host : Rita rita (Ham.).

LOCATION : Intestine.

LOCALITY : Lucknow.

Discussion: The present form belongs to A. thapari Gupta, 1950 but differs from it in the possession of an esophagus and in the relative size of various organs. These characters ate considered as specific variations. 


\section{ALLOCREADIUM MEHRAI Gupta, 1956 (Figs. 14-15)}

Syn. Rhynchocreadium aculeata Srivastava, 1962, R. singhia Pershad, 1965 and A. spindale Saksena, 1958.

Four specimens were collected from the intestine of a fresh water eel, Rhynchobdella aculeata (Bloch.) from river Gomati at Lucknow.

Description : Body elongated, aspinose, rounded at extremities, 2.85 to $4.93 \mathrm{~mm}$. long, 0.55 to $0.90 \mathrm{~mm}$. wide in region of ventral sucker. Oral sucker subterminal,
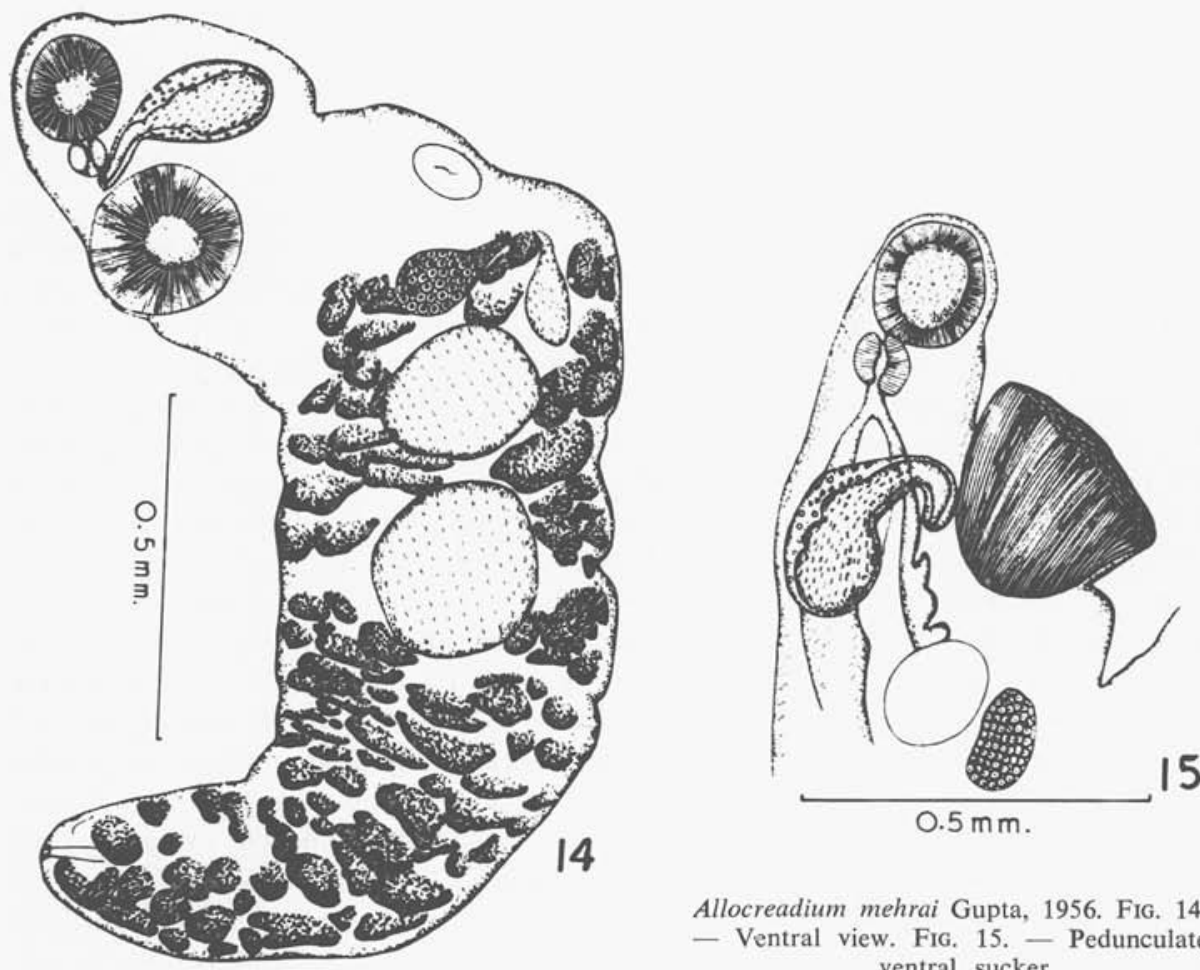

Allocreadium mehrai Gupta, 1956. FIG. 14. - Ventral view. FIG. 15. - Pedunculate ventral sucker

oval, 0.20 to $0.29 \mathrm{~mm}$. long, 0.19 to $0.25 \mathrm{~mm}$. wide. Ventral sucker pedunculate, larger than oral sucker, 0.31 to $0.39 \mathrm{~mm}$. long, 0.06 to $0.12 \mathrm{~mm}$. wide at 0.30 to $0.62 \mathrm{~mm}$. from anterior extremity. Prepharynx absent ; pharynx ovoid, muscular, 0.08 to $0.12 \mathrm{~mm}$. long, 0.06 to $0.12 \mathrm{~mm}$. wide ; esophagus tubular, shorter than pharynx, 0.07 to $0.085 \mathrm{~mm}$. long ; caeca simple extending upto hind end of body.

Genital pore median or submedian, lying infront of ventral sucker at 0.38 to $0.50 \mathrm{~mm}$. from anterior extremity. 
Excretory pore terminal ; bladder tubular, extending upto hind end of posterior testis.

Testes entire, ovoid or spherical, tandem and lying in middle of body. Anterior testis, 0.18 to $0.31 \mathrm{~mm}$. long, 0.19 to $0.39 \mathrm{~mm}$. wide at 1.01 to $1.59 \mathrm{~mm}$. from anterior extremity. Posterior testis larger than anterior testis lying close to anterior testis, 0.25 to $0.42 \mathrm{~mm}$. long, 0.21 to $0.39 \mathrm{~mm}$. wide at 1.0 to $2.9 \mathrm{~mm}$. from hind end of body. Cirrus sac flask shaped lying infront of ventral sucker, 0.40 to $0.57 \mathrm{~mm}$. long, 0.14 to $0.50 \mathrm{~mm}$. wide at 0.3 to $0.4 \mathrm{~mm}$. from anterior extremity. Vesicula seminalis bipartite and lying in basal part of cirrus sac; proximal part 0.12 to $0.19 \mathrm{~mm}$. long, 0.12 to $0.25 \mathrm{~mm}$. wide while distal part $0.1 \mathrm{~mm}$. long, $0.09 \mathrm{~mm}$. wide. Anterior to vesicula seminalis a pars prostatica, 0.05 to $0.06 \mathrm{~mm}$. long, 0.01 to $0.02 \mathrm{~mm}$. wide opening into a muscular cirrus through an ejaculatory duct, 0.1 to $0.12 \mathrm{~mm}$. long. Space around vesicula seminalis and pars prostatica surrounded by a large number of prostate gland cells.

Ovary entire, oval or spherical, pre testicular, pre equatorial between ventral sucker and anterior testis, 0.1 to $0.22 \mathrm{~mm}$. long, 0.15 to $0.31 \mathrm{~mm}$. wide at 0.72 to $1.3 \mathrm{~mm}$. from anterior extremity. Receptaculum seminis pear shaped, lateral to ovary and infront of anterior testis, 0.1-0.2 mm. long, 0.12-0.59 mm. wide at 0.81-1.08 mm. from anterior extremity. Vitellaria follicular extending from anterior region of ovary upto a little infront of hind end of body, mainly lateral in position but oover intestinal caeca and extend at places in intercaecal space behind posterior testis. Uterine coils lying between ovary and genital pore. Eggs oval, few in number, 0.16 to $0.20 \mathrm{~mm}$. long, $0.11 \mathrm{~mm}$. to $0.12 \mathrm{~mm}$. wide.

Host : Rhynchobdella aculeata (Bloch.).

LOCATION : Intestine.

LOCALITY : Lucknow.

Discussion : The present form belongs to A. mehrai Gupta, 1956 but differe from it in having ventral sucker at a distance of $1 / 6$ th to $1 / 10$ th instead of $1 / 5$ th from anterior extremity and in the position of genital pore and receptaculum seminis.

Saksena (1958) described A. spindale from a fresh water fish Mastacembelus armatus and distinguished it from A. mehrai in the possession of a small prepharynx and in having oval vesicula seminalis. In the opinion of author these characters are specific variations and hence $A$. spinda'e is a synonym of $A$. mehrai.

Srivastava (1962) created a new genus Rhynchocreadium with $R$. aculeata as type species from Rhynchobdella aculeata. The description as well as the drawings of $R$. aculeata showed a striking resamblance to those of $A$. mehrai Gupta, 1956. I believe that Rhynchocreadium Srivastava, 1962 is identical to Allocreadium. Therefore $R$. aculeata becomes a new combination $A$. aculeata and $R$. singhia a new comb. as A. singhia, A. aculeata differs from A. mehrai in the position of ovary in relation to ventral sucker, in the extension of excretory bladder and in having equal testes. However these differences are specific variations and hence are identical. 


\section{ALLOCREADIUM SINGHI Rai, 1962 (Figs. 16).}

A single specimen of this form was collected from the intestine of a fresh water fish, Rita rita (Ham.) from river Gomati at Lucknow.

DesCription : Body elongated, aspinose, rounded at extremities, $3.07 \mathrm{~mm}$. long, $1.31 \mathrm{~mm}$. wide. Oral sucker terminal, oval, $0.36 \mathrm{~mm}$. long, $0.40 \mathrm{~mm}$. wide. Ventral sucker subspherical, smaller than oral sucker, $0.34 \mathrm{~mm}$. long, $0.39 \mathrm{~mm}$. wide at $0.71 \mathrm{~mm} .1 / 3 \mathrm{rd}$ from anterior extremity. Prepharynx absent ; pharynx oval, $0.19 \mathrm{~mm}$. long, $0.22 \mathrm{~mm}$. wide; esophagus very short; ceaca terminating nearly half way between posterior testis and hind end of body.

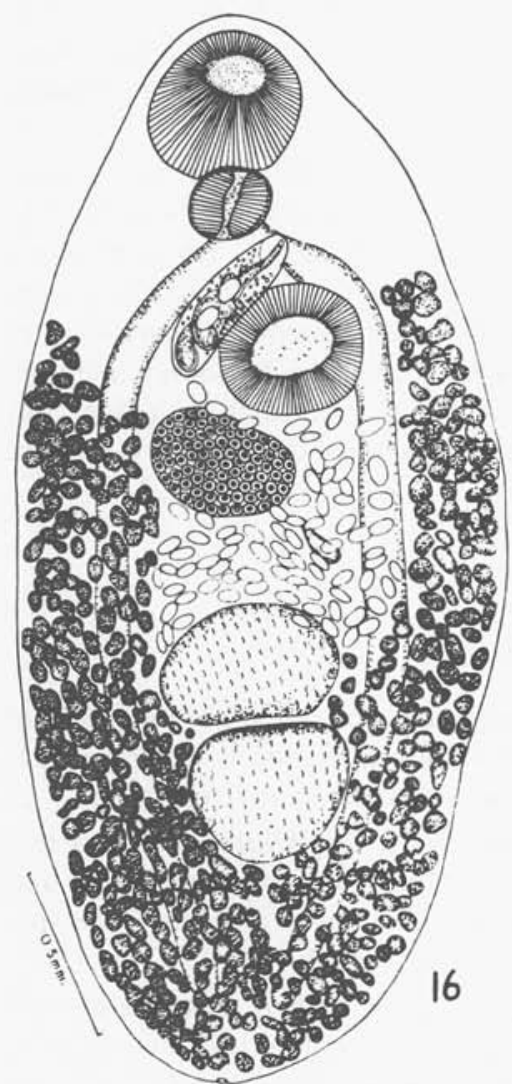

FIG. 16. - Allocreadium singhi Rai, 1962 Dorsal view

Genital pore on left side nearly at level of intestinal bifurcation at $0.6 \mathrm{~mm}$. from anterior extremity.

Excretory pore terminal; bladder tubular extending upto hind end of body.

Testes entire, oval, postequatorial, tandem, lying in anterior half of hind end of body. Anterior testis $0.31 \mathrm{~mm}$. long, $0.49 \mathrm{~mm}$. wide at $1.49 \mathrm{~mm}$. from anterior end. Posterior testis lying just behind anterior testis, larger than anterior testis, $0.38 \mathrm{~mm}$. long, $0.42 \mathrm{~mm}$. wide at $0.60 \mathrm{~mm}$. from hind end of body. Cirrus sac flask shaped, extending from intestinal bifurcation upto middle of ventral sucker, $0.45 \mathrm{~mm}$. long, $0.10 \mathrm{~mm}$. wide at $0.59 \mathrm{~mm}$. from anterior extremity. Vesicula seminalis lying in basal part of cirrus sac, spirally twisted, $0.3 \mathrm{~mm}$. long, $0.1 \mathrm{~mm}$. wide ; pars prostatica $0.07 \mathrm{~mm}$. long; ejaculatory duct $0.18 \mathrm{~mm}$. long. Space around vesicula seminalis and pars prostatica in cirrus sac filled with prostate gland cells.

Ovary entire, oval, preequatorial, just behind ventral sucker, $0.39 \mathrm{~mm}$. long, $0.25 \mathrm{~mm}$. wide at $1.1 \mathrm{~mm}$. from anterior extremity. Receptaculum seminis pear shaped, $0.1 \mathrm{~mm}$. long, $0.05 \mathrm{~mm}$. wide at $1.35 \mathrm{~mm}$. from anterior extremity. Vitellaria follicular, extending from anterior end of ventral sucker to hind of body, main:y lateral in position but cover intestinal ceca and space behind posterio testis. Uterine coils lie between genital pore and anterior region of anterior testis. Eggs oval and operculated, 0.08 to $0.1 \mathrm{~mm}$. long, 0.03 to $0.05 \mathrm{~mm}$. wide. 
Host : Rita rita (Ham.).

LOCATION : Intestine.

LOCALITY : Lucknow.

Discussion : The present form belongs to A. singhi Rai, 1962 but however differs from it in having ventral sucker smaller than oral sucker, in the absence of prepharynx and in the extension of uterine coils between genital pore and anterior region of anterior testis and in having a new host. These differences are considered as specific variations.

\section{ALLOCREADIUM HETEROPNEUSTUSIUS Agrawal, 1964.}

Three specimens were collected from the intestine of a fresh water fish Mystus seenghala (Skyes) obtained from the local market at Lucknow.

Description: body, 1.36 to $3.16 \mathrm{~mm}$. long, 0.34 to $0.80 \mathrm{~mm}$. wide. Oral sucker, 0.2 to $0.3 \mathrm{~mm}$. long, 0.21 to $0.23 \mathrm{~mm}$. wide. Ventral sucker preequatorial, 0.13 to $0.25 \mathrm{~mm}$. long, 0.14 to $0.25 \mathrm{~mm}$. wide at 0.37 to $0.69 \mathrm{~mm}$. from anterior extremity. Prepharynx absent: pharynx, 0.05 to $0.11 \mathrm{~mm}$. long, 0.09 to $0.016 \mathrm{~mm}$. wide ; esophagus tubular, 0.045 to $0.05 \mathrm{~mm}$. long; ceca extending to hind end of body.

Genital pore at $0.45 \mathrm{~mm}$. from anterior extremity and lying midway between oral sucker and ventral sucker.

Excretory pore terminal ; bladder tubular extending upto hind end of posterior estis.

Testes entire, tandem and lying in middle of body. Anterior testis 0.14 to $0.25 \mathrm{~mm}$. long, 0.14 to $0.23 \mathrm{~mm}$. wide at 0.60 to $1.36 \mathrm{~mm}$. from anterior extremity. Posterior testis larger than anterior and lies close to anterior testis, 0.13 to $0.32 \mathrm{~mm}$. long, 0.13 to $0.23 \mathrm{~mm}$. wide at 0.05 o $0.12 \mathrm{~mm}$. from hind end of body. Cirrus sac flask shaped, lying obliquely between ventral sucker and intestinal bifurcation, $0.18 \mathrm{~mm}$. long, $0.07 \mathrm{~mm}$. wide at $0.5 \mathrm{~mm}$. from anterior end.

Ovary postacetabular, lying on lateral side of anterior testis, 0.10 to $0.25 \mathrm{~mm}$. long, 0.10 to $0.15 \mathrm{~mm}$. wide at $0.49 \mathrm{~mm}$. from anterior extremity. Receptaculum seminis pear shaped, lying laterally on right side of ovary, $0.13 \mathrm{~mm}$. long, $0.1 \mathrm{~mm}$. wide at $1.19 \mathrm{~mm}$. from anterior extremity. Vitellaria extending from middle of ovary to hind end of ventral sucker, mainly lateral in position covering intestinal ceca and back to posterior testis filling intercaecal space. Uterus form few coils between anterior testis and ventral sucker. Eggs, 0.10 to $0.105 \mathrm{~mm}$. long, 0.12 to $0.13 \mathrm{~mm}$. wide.

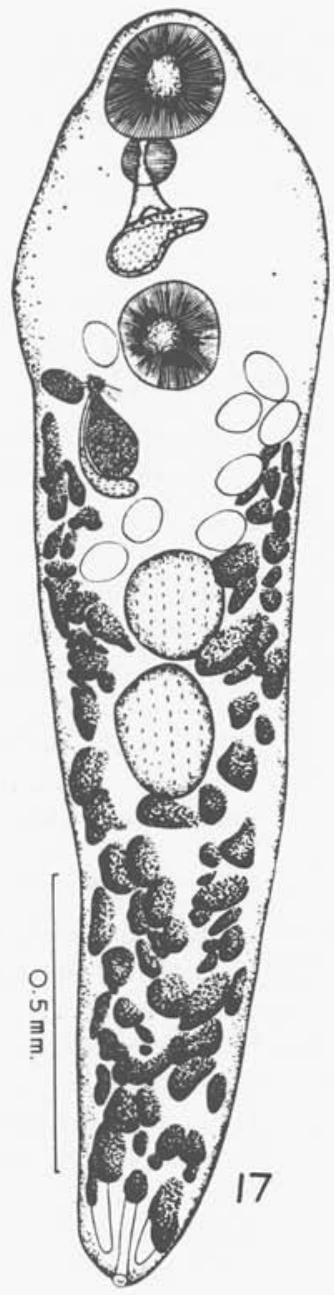

FIG. 17. - Allocreadium heteropneustusius Agrawal, 1964 dorsal view 
Host : Mystus seenghala (Skyes).

LOCATION : Intestine.

LOCALITY : Lucknow.

Discussion : The present form belongs to A. heteropneustusius Agrawal, 1964 but however differs from it in having receptaculum seminis dorsolateral to ovary, in the relative size of ventral sucker and in having a new host. These differences are considered as specific variations.

Key to the Indian species of Ailocreadium Looss, 1900.

A. Cirrus pouch extending beyond ventral sucker

a) Cirrus pouch extending upto anterior end of ovary $\ldots \ldots \ldots \ldots \ldots \ldots \ldots$. dollfusi Cirrus pouch not extending upto anterior end of ovary $\ldots \ldots \ldots \ldots \ldots \ldots \ldots \ldots \ldots .$.

b) Vitellaria extending from midway between esophagus and intestinal bifurcation to hind

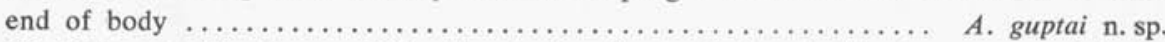
Vitellaria extending from middle of ventral sucker to hind end of body ...... A. kosia.

B. Cirrus pouch not extending beyond ventral sucker

x) Cirrus pouch extending upto hind end of ventral sucker $\ldots \ldots \ldots \ldots \ldots$. hirnai Cirrus pouch extending upto middle of ventral sucker $\ldots \ldots \ldots \ldots \ldots \ldots \ldots \ldots$, y.

y) Vitellaria extending from anterior end of ventral sucker to hind end of body.

1. Excretory bladder spherical ....................... nemachilus

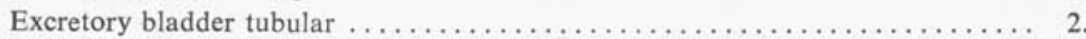

2. Genital pore intercæcal ........................... A. singhi Genital pore extracæcal ............................. nicolli

Vitellaria extending from middle of ventral sucker to hind end of body .. A. makundi Vitellaria extending from hind end of ventral sucker to posterior end of body.

Uterine coils extending from ventral sucker to anterior end of posterior testis

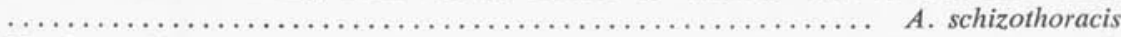
Uterine coils extending from ventral sucker upto anterior end of anterior testis

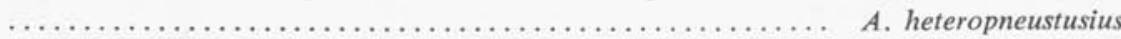
Vitellaria extending from anterior end of ovary to hind end of body .. A. Mehrai

C. Cirrus pouch extending anterior to ventral sucker

Vitellaria extending from hind end of oral sucker to hind end of body .. A. kamalai Vitellaria extending from intestinal bifurcation to hind end of body $\ldots \ldots \ldots \ldots \ldots$.

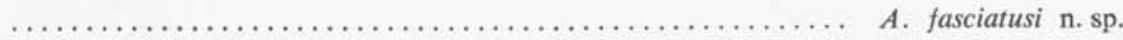
Vitellaria extending from hind end of ventral sucker to posterior end of body. Testes lying in extreme posterior end of body $\ldots \ldots \ldots \ldots \ldots \ldots . . . \ldots \ldots n n a n d a l e i$ Testes not lying in the extreme posterior end of body.

Receptaculum seminis lying on postero-lateral to ovary and infront of anterior

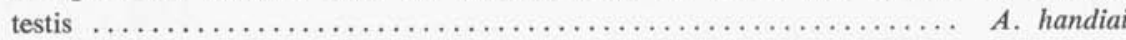
Receptaculum seminis lying postero dorsal to ovary just infront of anterior testis

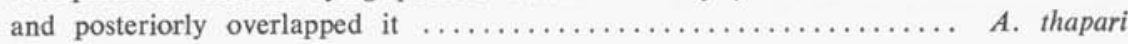




\section{References}

Agrawal (V.), 1964. - On some new trematodes from fresh water fishes of Lucknow. Ind. Jour. Helm. $16: 82-99$.

GuptA (S. P.), 1950. - On a new trematode, Allocreadium thapari n. sp. of the subfamily Allocreadiinae Looss, 1899 from the intestine of a fresh water fish, Rita rita (Ham.). Ind. Jour. Helm., 2: 17-22.

-, 1956. - Two new trematodes of the family Allocreadiidae from the fresh water fishes of U.P. Ind. Jour. Helm., 8 : 100-106.

-, 1962. - On two new trematodes (Family: Allocreadiidae Stossich, 1903) from the intestine of fresh water fishes of Banaras, U.P. Proc. Helm. Soc. Wash., 30: 96-100.

KaW (B. L.), 1950. - Studies in Helminthology: Helminth parasites of Kashmir. Part. I. Trematoda. Ind. Jour. Helm. 2: 67-126.

Mehra (H. R.), 1966. - Revision of Allocreadioidea Nicoll, 1934. Part. I. Families: Opecoelidae Ozaki, 1925, Opistholebetidae Fukui, 1929, Allocreadiidae Stossich, 1903, Bunoderidae Nicoll, 1914, Acanthocolpidae Luhe, 1909 and Pleorchiidae Poche, 1925. M. K. Dikshit et Dikshit Press, Allahabad.: 1-46

PANDE (B. P.), 1937. - Morphology and relationships of a new digenetic trematode from an Indian fresh water fish, ophicephalus punctatus. Ann. Mag. Nat. Hist. Ser, $10,20: 415-421$.

-, 1938. - On two new trematodes from Indian Cyprinoid fishes with remarks on the genus Allocreadium Looss. Proc. Nat. Acad. Sci. 8: 110-115.

-, 1938. - The trematode genus Allocreadium in North Indian fresh water fishes. Proc. Ind. Acad. Sci. $7:$ 54-60.

PERSHAD (R.S.), 1965. - On a new species of the genus Rhynchocreadium Srivastava, 1962, from the fresh water fish, Rhynchobdella aculeata in Hyderabad, Andhra Pradesh. Zool. Anz. Bd. 175 : 4-6.

RAI (S. L.), 1962. - Studies on three new species of the genus Allocreadium Looss, 1900 from the intestine of Barbus tor. (Ham.). Parasit. 52: 23-30.

SAKSENA (J. N.), 1958. - On a new species of genus Allocreadium Looss 1900, of the family Allocreadiidae Stossich 1904. Trematoda from the intestine of Mastacembelus armatus. Proc. Nat. Acad. Sci. 27 : 227-230.

SRIVAStAVA (C. B.), 1962. - A new Allocreadiid trematode, Rhynchocreadium aculeata gen et sp. nov., from the fresh water eel, Rhynchobdella aculeata Bloch. Ind. Jour. Helm. $14: 1-4$.

SRivastava (P.S.), 1960. - On a new trematode Allocreadium ophiocephali n. sp. of the family Allocreadiidae Stossich, 1904 from the intestine of Ophicephalus punctatus. Ind. Jour. Helm. 12: 108-113.

Southwell (T.), 1913. - Notes from the Bengal fisheries Laboratory; Indian Museum. No. I. Rec. Ind. Mus. 9: 79-103.

YAMAGUTI (S.), 1958. - Systema Helminthum. Interscience Publishers. New York. London. Vol. 1 \& 2. : 1-979. 